\title{
Rural Areas Risk Being Overlooked in 2010 Census
}

\author{
W IL LIA M P. O’HARE
}

\section{$\mathrm{T}$}

The 2010 decennial census is rapidly approaching, and the data collected this year will have ramifications for the next decade. At current values, over the next ten years, the government will distribute more than four trillion dollars to states and localities on the basis of formulas using census data. Table 1 lists the top ten federal programs that provided money to states and localities in fiscal year 2007 at least in part on the basis of census data.

The decennial census is intended to provide a complete count of the U.S. population, but some areas and some populations are more difficult to count accurately. There has been little public discussion of how the census might differ in rural, urban, and suburban areas. ${ }^{1}$ This issue brief describes how the census is conducted in rural areas, identifies some of the most difficult rural areas to count, and highlights what organizations are doing to ensure a more accurate census count in rural America, where nearly onefifth of the nation's population lives.

\section{Rural Areas Too Often Overlooked}

Historically, census evaluations have shown that the same groups tend to be undercounted each decade. ${ }^{2}$ These groups include racial minorities (particularly blacks, Hispanics, and American Indians), men, young adults, young children, and renters. In general, socially and economically marginalized groups tend to be harder to count accurately.

Rural areas have several characteristics that raise the

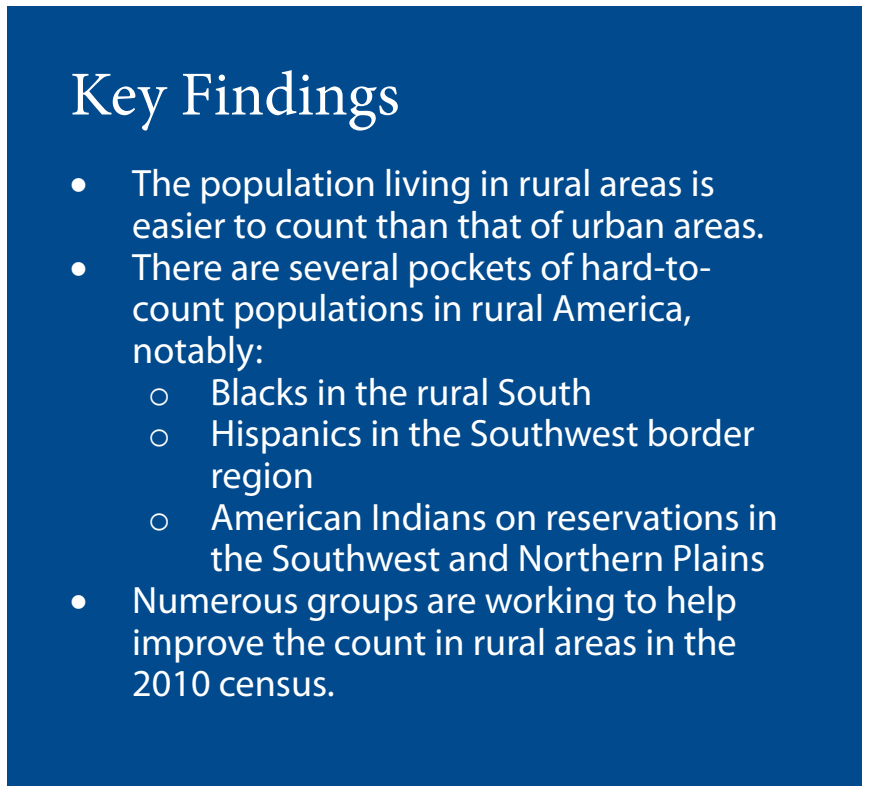

risk of undercounting. The risk of undercount in rural America occurs mostly for groups already disadvantaged by high poverty and low levels of education. ${ }^{3}$ In certain cases, the census misses large segments of the rural population. For example, an internal analysis of the 1990 census found that nearly 13 percent of people living on an American Indian reservation were missed compared with less than 2 percent in the overall census. ${ }^{4}$ 
TABLE 1. TOP TEN FEDERAL PROGRAMS THAT DISTRIBUTE FUNDS TO STATES AND LOCALITIES BASED AT LEAST PARTLY ON CENSUS DATA (FISCAL YEAR 2007)

\begin{tabular}{llrr} 
& Program name & Department or agency & $\begin{array}{c}\text { Fiscal Year 2007 } \\
\text { Obligation }\end{array}$ \\
1. & Medical Assistance Program & Health and Human Services & $\$ 203,499,801,000$ \\
2. & Unemployment insurance & Labor & $\$ 35,893,000,000$ \\
3. & Highway planning and construction & Transportation & $\$ 34,154,000,000$ \\
4. & Supplemental nutrition assistance program & Agriculture & $\$ 30,319,569,235$ \\
5. & Temporary assistance for needy families & Health and Human Services & $\$ 16,479,811,000$ \\
6. & Federal Pell Grant Program & Education & $\$ 13,660,771,000$ \\
7. & Title I grants to local educational agencies & Education & $\$ 12,838,123,000$ \\
\hline 8. & Special education grants to states & Education & $\$ 10,782,961,000$ \\
9. & National School Lunch Program & Agriculture & $\$ 7,836,173,913$ \\
10. & Head Start & Health and Human Services & $\$ 6,868,508,728$
\end{tabular}

Source: Lisa M. Blumerman and Phillip M. Vidal, "Uses of Population and Income Statistics in Federal Funds Distribution- With a Focus on U.S. Census Bureau Data” (Government Divisions Report Series, Research Report No. 2009-1, U.S. Census Bureau, 2009).

\section{Some Reasons Why Rural Areas are Difficult to Count}

Several conditions unique to rural areas are pertinent to the census. For example, high-amenity areas and vacation destinations in rural America create more seasonal tourism jobs. The census is taken on April 1, typically a low-demand period for both seasonal work and tourism. As a result, individuals who live in these rural areas at other times of the year may not be living there on census day.

Temporary employment is also higher in rural areas, in part because seasonal work in agricultural, timber, or fishing industries is more prevalent in rural areas. These jobs often lead to greater mobility, which hinders getting an accurate population count, particularly among migrant and seasonal farmworkers. This population is not only highly mobile (especially in the spring and summer when the census is underway), but their living arrangements are often not standard housing units, which can make them difficult to count. ${ }^{5}$ In addition to housing characteristics, language, literacy, and distrust of outsiders may also contribute to a potential undercount. ${ }^{6}$ To address some of these issues, the U.S. Census Bureau recently studied where migrant and seasonal farmworkers reside, which may improve accuracy of the count.?

In addition to seasonal work, the large share of seasonal or vacation homes in rural America complicates the census.
The 2007 American Housing Survey shows that 52 percent of the 4.4 million seasonal units are located outside metropolitan areas. ${ }^{8}$ The seasonal units are heavily concentrated in the Midwest and South. For the decennial census, respondents who own two (or more) homes are asked to respond from the place they live most of the time. However, for many people who split their time between two or more homes, this stipulation may be unclear, and they may respond from the address where they first received the form, or they may return forms from both homes. Some areas with large numbers of vacation or seasonal homes may actually experience an over count.

In addition, large-city census efforts are often better funded, placing small rural communities at a relative disadvantage. One review of the 2000 census concluded, "Counties that are more rural and smaller in population probably have the least resources and may want the most help from the U.S. Census Bureau." Given the current economic situation, funds for census promotion and outreach are even more difficult to find.

In most parts of the nation, the census will be conducted by mailing out questionnaires to a list of addresses, asking respondents to mail back the completed form, and following up with those households that do not return the form by mail. But in many rural areas where conventional city-style addresses are not available, the U.S. Census Bureau will use alternative methods (see Box 1). 
Box 1: Taking the Decennial Census-the Basics

The three main types of enumeration methods in the decennial census include the following:

1. Mailout/mailback areas-the vast majority of the country will receive a questionnaire in the mail, and if they do not send it back to the U.S. Census Bureau, an enumerator will come to their door to collect the data.

2. Update/leave-in many rural areas where addresses are not tied to a specific location (rural route numbers, for example), census enumerators drop off address-labeled questionnaires in their assigned areas. Respondents then mail the questionnaires. If no questionnaire is received from a housing unit, enumerators are sent to the household to get the data.

3. List/enumerate-in remote, sparsely populated, and hard-to-visit areas, enumerators searching for housing units list each one found in an address registry and enumerate the household at the same time.

Needless to say, the second and third types of enumeration areas are more prevalent in rural areas. However, there is no evidence that quality and completeness of data collected are any different among the three areas.
TABLE 2. MEASURES USED TO IDENTIFY HARD-TO-COUNT AREAS

\begin{tabular}{|c|c|c|c|}
\hline & $\begin{array}{c}\text { Total } \\
\text { United } \\
\text { States }\end{array}$ & $\begin{array}{l}\text { Urban } \\
\text { (inside } \\
\text { metro } \\
\text { areas) }\end{array}$ & $\begin{array}{c}\text { Rural } \\
\text { (outside } \\
\text { metro } \\
\text { areas) }\end{array}$ \\
\hline $\begin{array}{l}\text { Percent of housing } \\
\text { units that are vacant }\end{array}$ & 12 & 11 & 19 \\
\hline $\begin{array}{l}\text { Percent of housing units that } \\
\text { are not single detached or attached }\end{array}$ & 38 & 40 & 29 \\
\hline $\begin{array}{l}\text { Percent of housing units } \\
\text { that are renter-occupied }\end{array}$ & 33 & 35 & 28 \\
\hline $\begin{array}{l}\text { Percent of housing units with more } \\
\text { than } 1.5 \text { persons per room }\end{array}$ & 1 & 1 & 1 \\
\hline $\begin{array}{l}\text { Percent of households that } \\
\text { are not husband-wife }\end{array}$ & 51 & 51 & 48 \\
\hline $\begin{array}{l}\text { Percent of housing units that } \\
\text { are without a telephone }\end{array}$ & 2 & 2 & 2 \\
\hline $\begin{array}{l}\text { Percent of adults (over age 25) } \\
\text { who are not high school graduates }\end{array}$ & 15 & 15 & 18 \\
\hline $\begin{array}{l}\text { Percent of persons below } \\
\text { the poverty level }\end{array}$ & 13 & 13 & 16 \\
\hline $\begin{array}{l}\text { Percent of households receiving } \\
\text { cash public assistance income }\end{array}$ & 2 & 2 & 2 \\
\hline Percent unemployed & 6 & 6 & 7 \\
\hline $\begin{array}{l}\text { Percent of households that } \\
\text { are linguistically isolated }\end{array}$ & 5 & 6 & 2 \\
\hline $\begin{array}{l}\text { Percent of households who } \\
\text { moved into a unit in the last year }\end{array}$ & 16 & 16 & 15 \\
\hline
\end{tabular}

Source: U.S. Census Bureau, 2008 American Community Survey, American Factfinder, Tables B25002, B25024, B25003, B25014, B11001, C25043, C15002, C17001, B19057, C23001, B16002, and C07001.

On the other hand, rural areas have several characteristics that make them easier to count accurately, including the following:

- A higher percentage of rural residents who live in single, detached homes

- A higher share of husband-wife households

- Relatively fewer rental units than non-rural areas

- Relatively fewer linguistically isolated households

On the basis of the twelve characteristics associated with undercounts, the U.S. Census Bureau has assigned every census tract in the country a hard-to-count score. ${ }^{11}$ Using the hard-to-count scores, the percent of the population in each county that lives in a hard-to-count area was calculated. ${ }^{12}$ Table 3 shows that only 9 percent of the rural 
MAP 1. The Ten PERCENT OF COUNTIES (310) WITH THE HIGHEST HARD-TO-COUNT SCORES BY METRO STATUS

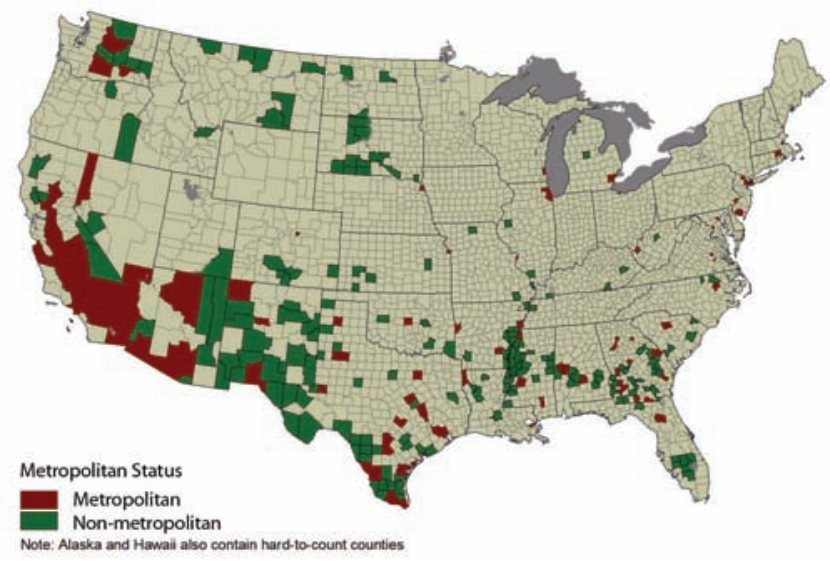

population live in hard-to-count areas compared to 19 percent of the urban population.

Map 1 shows the 310 hardest-to-count counties by metro status. ${ }^{13}$ About two-thirds (212) of the hard-to-count counties are rural. It is also worth noting that many of the counties classified as metro because they have a large city also contain significant rural areas. For example, many of the counties in the central valley of California fall in this category.

Even though Table 3 shows that rural areas on average are not as difficult to count as urban areas, they make up a large share of the counties that are hardest to count.

Furthermore, in 126 counties where more than half the population lived in hard-to-count areas, 99 were located outside metropolitan areas. Among the 36 counties where 100 percent of the population lives in hard-to-count areas, 34 were rural counties.

\section{Minorities in Rural Areas Among the Most Likely to be Missed in the Census}

Since the first evaluations of the census more than fifty years ago, studies have consistently found that racial and ethnic minorities are undercounted more often than whites. Although 9 percent of the overall rural population lives in the 212 hardest-to-count counties, 23 percent of rural blacks reside there, and about one-third of rural American Indians (including Alaskan natives) and onethird of rural Hispanics live in these counties (see Table 4).
TABLE 3. HARD-TO-COUNT POPULATION FIGURES INSIDE AND OUTSIDE METRO AREAS

\begin{tabular}{lccc} 
& \multicolumn{1}{c}{$\begin{array}{c}\text { Potal } \\
\text { population } \\
\text { Country }\end{array}$} & $\begin{array}{c}\text { hiving in } \\
\text { hard-to-count } \\
\text { areas }\end{array}$ & $\begin{array}{c}\text { Percent of } \\
\text { population in } \\
\text { hard-to-count } \\
\text { areas }\end{array}$ \\
$\begin{array}{l}\text { Urban (inside } \\
\text { metro areas }\end{array}$ & $232,579,940$ & $45,325,483$ & $19 \%$ \\
$\begin{array}{l}\text { Rural (outside } \\
\text { metro areas) }\end{array}$ & $48,841,966$ & $4,360,203$ & $9 \%$ \\
\hline Total & $281,421,906$ & $49,685,686$ & $18 \%$ \\
\hline
\end{tabular}

Source: U.S. Census Bureau 2010 Census Planning Data Base.

Note: For more information about the U.S. Census Bureau's Planning Data Base and hard-to-count scores, see http://www.census.gov/procur/ www/2010communications/tract\%20level\%20pdb\%20with\%20census\%20 2000\%20data\%2001-19-07.pdf.

In total, 48 percent of the population in the 212 hardestto-count rural counties is black, Hispanic, or American Indian/Alaskan native, even though these groups make up only 16 percent of the rural population.

\section{Black-Majority Counties}

Blacks were the majority population in forty-one of the top hardest-to-count rural counties. These counties are almost exclusively in the Deep South, with sixteen in Mississippi, seven in Georgia, and six in Alabama. Poverty, illiteracy, unemployment, and a history of oppression characterize many of these places, and these characteristics are linked to the likelihood of being missed in the census.

Southern Echo, which focuses on the Deep South, and Southern Coalition for Social Justice, which focuses on southeastern states, are two organizations with census mobilization initiatives that are attempting to make sure the U.S. Census Bureau gets a complete and accurate count in the rural South. By providing training and resources to local grass-roots groups in hard-to-count communities, these groups hope to eliminate or at least minimize a census undercount in 2010.

\section{Hispanic-Majority Counties}

Hispanics were the majority in twenty-six of the top hardestto-count rural counties. These counties were mostly in Texas (twenty of them), with four in New Mexico, and one each in Arizona and Colorado. Many are home to colonias along the southwest United States-Mexico border. ${ }^{14}$ These areas are 
TABle 4. Population In Hardest-TO-COUNT RURAL COUNTIES COMPARED TO TOTAL RURAL POPULATION By RACE

\begin{tabular}{lccc} 
& $\begin{array}{c}\text { Population in ten percent } \\
\text { of hardest-to-count } \\
\text { rural counties }\end{array}$ & $\begin{array}{c}\text { Total rural n } \\
\text { population } \\
\text { in this group }\end{array}$ & $\begin{array}{c}\text { Percent of group in } \\
\text { top ten percent of } \\
\text { hard-to-count counties }\end{array}$ \\
\hline Total & $4,480,334$ & $48,841,966$ & $9 \%$ \\
\hline White & $2,740,384$ & $41,522,080$ & $7 \%$ \\
\hline Black & 944,937 & $4,150,069$ & $23 \%$ \\
\hline $\begin{array}{l}\text { American Indian/ } \\
\text { Alaskan native }\end{array}$ & 360,450 & 953,232 & $38 \%$ \\
Asian & 32,838 & 359,361 & $9 \%$ \\
\hline $\begin{array}{l}\text { Hispanic } \\
\text { Non-Hispanic white }\end{array}$ & 834,582 & $2,632,515$ & $32 \%$ \\
\hline $\begin{array}{l}\text { Black, American Indian, } \\
\text { and Hispanic }\end{array}$ & $2,276,410$ & $40,184,690$ & $6 \%$ \\
$\begin{array}{l}\text { Black, American Indian, } \\
\text { and Hispanic percent of total }\end{array}$ & $2,139,969$ & $7,735,816$ & $27 \%$ \\
\hline
\end{tabular}

Source: U.S. Census Bureau 2010 Census Planning Data Base.

Note: For more information about the U.S. Census Bureau's Planning Data Base and hard-to-count scores, see http://www.census.gov/procur/ www/2010communications/tract\%20level\%20pdb\%20with\%20census\%202000\%20data\%2001-19-07.pdf.

hard to count for because of irregular housing, little or no knowledge of Engish, limited formal education, and concerns regarding confidentiality. ${ }^{15}$

As we move toward the 2010 census, it is also important to recognize that the Hispanic population is growing rapidly in places where there were few Hispanics ten years ago. ${ }^{16}$ For many rural areas, the 2010 census will be the first one where the community has large numbers of Latinos.

The Frontera Asset Building Network and the National Association of Latino Elected and Appointed Officials (NALEO) are two groups working to raise awareness of the importance of the census among hard-to-count populations in the rural Southwest and the United States-Mexico border. NALEO is also a partner in the Leadership Conference on Civil Rights Education Fund census project.

\section{American Indian Country}

American Indians and Alaska natives constituted more than half the population in 23 of 212 rural counties in the top hardest-to-count counties. These groups are found mostly in Alaska and South Dakota, with eight counties each in these two states. There were also three counties in Montana and one each in Arizona, New Mexico, Utah, and North Dakota.

The National Congress of American Indians (NCAI) has developed a 2010 census tool kit to provide advocates with information about the census and the kind of messages that are likely to motivate American Indians to ensure they are counted. The NCAI is also a partner in the Leadership Conference on Civil Rights Education Fund census project. In addition, the Denver regional office of the U.S. Census Bureau has developed a regular newsletter to increase census awareness among American Indians in that region.

\section{Long-Term Ramifications for Rural America}

Undercounted communities do not receive their fair share of public funds for things such as schools, hospitals, day care centers, and roads. Rural communities that are already struggling in this economic climate can ill-afford to lose federal money because they are not fully counted in the census. Moreover, inaccurate census data provide a skewed picture of rural communities.

There is a sharp racial overlay to the hard-to-count rural areas. Without special attention, the population in these areas is in jeopardy of being undercounted in the decennial census, which means they will be deprived of their rightful share of political power and government resources. Since data from the 2010 decennial census will be used for the next decade, mistakes made now will have consequences for years to come. 


\section{Endnotes}

1. The terms urban and metro are used interchangeably in this report, as are rural and non-metro.

2. For a good overview of census undercounts, see National Research Council, “The 2000 Census: Counting Under Adversity," Panel to Review the 2000 census, Constance F. Citro, Daniel L Cork, and Janet L. Norwood, eds., (Washington, D.C.: Committee on National Statistics, Division of Behavioral and Social Science and Education, The National Academies Press, 2004).

3. Evaluation of the 1990 census provides some information on the undercounts among rural residents, but no such analysis was conducted following the 2000 census. For the 1990 census evaluation, see Kirsten K. West and J. Gregory Robinson, "What Do We Know about the Undercount of Children?” (U.S. Census Bureau, Population Division Working Paper No. 39, August 1999), Appendix table 2, http://www.census.gov/population/www/documentation/ twps0039/twps0039.html.

4. Howard Hogan and Gregg Robinson, "What the U.S. Census Bureau's Coverage Evaluation Programs Tell Us about Differential Undercount" (paper presented at the Research Conference on Undercounted Ethnic Populations, Richmond, Virginia, May 5-7, 1993), Table 3.

5. Susan Gabbard, Ed Kissam, and Phillip Martin, “The Impact of Migrant Travel Patterns on the Undercount of Hispanic Farm Workers," in Proceedings of the Bureau of the Census Research Conference on Undercounted ethnic Populations, (Richmond, VA: U.S. Census Bureau, May 1993).

6. U.S. General Accounting Office, "Decennial Census: Lessons learned for Locating and Counting Migrant and Seasonal Farmworkers" GAO-03-605, July 2005.

7. Aguirre Division of JBS International, Inc. Identifying High Concentrations of Migrant and Seasonal Farmworkers, Contract Number 05-41823-0-0, Burlingame, CA.

8. U.S. Census Bureau American Housing Survey, http:// www.census.gov/hhes/www/housing/ahs/ahs07/ahs07.html.

9. U.S. Census Bureau, "Complete Count Committee Focus Groups: Final Report” (U.S. Census Bureau, January 2006), 9.

10. Census Planning Database, http://pdb.2010.census.gov/.

11. A census tract is a unit of geography created to take the census. It typically includes 2,000 to 8,000 people.

12. A cutoff score of 60 or more is used on the U.S. Census
Bureau Hard-to-Count index to identify hard-to-count census tracts.

13. These are counties where more than 27 percent of the population is living in hard-to-count areas. The national average is 8.7 percent. At 27 percent, these counties are among the top ten percent in terms of hard-to-count areas. The ten percent threshold is somewhat arbitrary, but it produces a large enough set of counties (310) to see patterns while still focusing on the most difficult to enumerate counties.

14. The U.S. Census Bureau describes colonias as "generally unincorporated and low income residential subdivisions, lacking basic infrastructure and services along the border between the U.S. and Mexico." See Manuel De La Puente, "Census 2000 Testing, Experimentation and Evaluation Program Topic Report 15," Census 2000 Ethnographic Studies, TR-15, (Washington, D.C.: U.S. Census Bureau, 2004), 12, http://www.census.gov/pred/www/rpts/TR15.pdf/

15. Manuel De La Puente, "Census 2000 Testing, Experimentation and Evaluation Program Topic Report 15," Census 2000 Ethnographic Studies, TR-15, (Washington, D.C.: U.S. Census Bureau, 2004), 2, http://www.census.gov/ pred/www/rpts/TR15.pdf.

16. Kenneth M. Johnson and Daniel T. Lichter, "Natural Increase: A New Source of Population Growth in Emerging Hispanic Destinations in the United States" Population and Development Review, Vol. 34, Issue 2, 2009): 327-346; Leif Jensen, New Immigrant Settlements in Rural America: Problems, Prospects, and Policies, A Carsey Institute Report on Rural America (Durham, NH: Carsey Institute, University of New Hampshire, 2006). 


\section{Resources}

The following are some general on-line resources related to the 2010 census and the U.S. Census Bureau:

U.S. Census Bureau: http://www.census.gov/2010census/ Regional census offices: http://www.census.gov/field/www/ 2010 census jobs: http://2010.census.gov/2010censusjobs/ American Farm Bureau Federation: http://www.fb.org/ California Rural Legal Assistance: http://www.crla.org/ National Congress of American Indians: http://www.ncai.org/ National Congress of American Indians tool kit: http://www. indiancountrycounts.org/home.cfm

California Indian Manpower Consortium: http://www. cimcinc.org/

First Alaskans Institute: http://www.firstalaskans.org/ Frontera Asset Building Network: http://www.fabnetwork.org/ Leadership Conference on Civil Rights: http://www.civilrights.org/ National Council of La Raza: http://www.nclr.org/ National Association of Latino Elected and Appointed Officials: http://www.naleo.org/

The Navajo Nation: http://www.navajobusiness.com/ New Mexico Indian Affairs Department: http://www.iad. state.nm.us/

Norfolk State University Center for Applied Research and Public Policy: http://www.fairdata2000.com/

Paso Del Norte Health Foundation (formerly the Center for Border Health Research): http://www.pdnhf.org/

Rural Community Assistance Partnerships, Inc.: http://www. rcap.org/

Sitting Bull College Census Information Center: http://www. sittingbull.edu/community/library/

Southern Coalition for Social Justice: http://www.southerncoalition.org/

Southern Echo: http://www.southernecho.org

\section{ACKNOWLEDGMents}

The author would like to thank Edwin Quiamboa for producing Map 1 and the reviewers for their comments.

\section{About the Author}

William O'Hare is a visiting senior fellow at the Carsey Institute(WOhare@aecf.org). 


\section{ANIVERSITY}

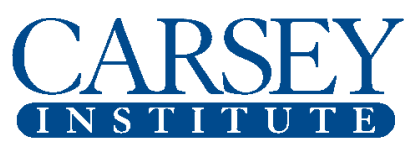

Building knowledge for families and communities

The Carsey Institute conducts policy research on vulnerable children, youth, and families and on sustainable community development. We give policy makers and practitioners timely, independent resources to effect change in their communities.

This work was supported by the Annie E. Casey Foundation's initiative to strengthen rural families, the W. K. Kellogg Foundation, and an anonymous donor.

Huddleston Hall

73 Main Street

Durham, NH 03824

(603) $862-2821$

www.carseyinstitute.unh.edu 